\title{
ANALISIS KERUSAKAN SAMBUNGAN LASAN PADA SISTEM VENTING PRE AIR COOLER DI LINGKUNGAN EKSPLORASI DAN PRODUKSI GAS ALAM
}

\author{
Kemal Arthur Uktolseja ${ }^{1}$, Margono Sugeng ${ }^{2}$ \\ Technical Support, Oil \& Gas Company ${ }^{1}$ \\ Dosen Prodi Teknik Mesin, Institut Sains dan Teknologi Nasional, Jakarta Selatan, Indonesia ${ }^{2}$ \\ email ${ }^{1}$ : Kemalarthur@hotmail.com
}

\begin{abstract}
The purpose of this study was to determine the cause of damage to the welded joints in the spool pipe on the pre-cooler air venting system in the natural gas exploration and production environment in the form of crack defects. The analysis was done by taking field data in the form of operational data and chemical content of fluid served, visual observation, chemical composition test with Optical Emission Spectrocopy, Hardness Testing using Rockwell scale B, Micro observation and makrophotograpy, Metalographic observation, microhardness testing using Vickers test plane, Observation of macro fracture surface using Scanning Electron Microscope. Based on the results of the tests and observations, it shows that the main cause of the damage is the brittle crack caused by the welding performance made possible by the use of higher current than required and rapid cooling of the welding of the thin material.
\end{abstract}

Keywords: crack of defect, austenitic staniless steel, brittle fructure

\section{PENDAHULUAN}

Kerusakan atau kegagalan pada suatu perangkat pada peralatan dalam kegiatan operasi di industri merupakan hal yang lazim terjadi. Kegagalan dapat disebabkan oleh kesalahan perancangan, kondisi operasi yang tidak sesuai dengan rancangan, kesalahan operator maupun dari permasalahan lain yang menyangkut peralatan tersebut. Kegagalan ini dapat didefinisikan sebagai ketidakmampuan suatu perangkat untuk berfungsi sebagaimana mestinya. Salah satu kegagalan pada perangkat adalah kegagalan mekanis, seperti: lendutan yang berlebihan, tekuk, patah ulet, patah getas, beban kejut, gesekan, dan korosi, yang menghasilkan bentuk retak permukaan dan indikator retak di dekat permukaan lainnya.

Pada penelitian ini dianalisa penyebab kerusakan yang terjadi pada sambungan lasan pada sistem venting pre air cooler di unit kompresi bagian tekanan menengah (medium pressure/MP) di dalam proses pengolahan awal gas alam. Untuk mengetahui akar permasalahan adanya kerusakan maka diperlukan adanya suatu analisa yang menyeluruh untuk mengetahui penyebab dari kegagalan tersebut, dengan kegiatan analisa yang dilakukan ini diharapkan dapat diketahui penyebab dari kegagalan yang terjadi ditinjau dari segi metalurginya, sehingga nantinya dapat diambil langkah-langkah pencegahan terjadinya kegagalan yang sama di kemudian hari.

\section{TINJAUAN PUSTAKA}

2.1. Produksi Gas Alam

Gas alam sering juga disebut sebagai gas bumi , adalah bahan bakar fosil berbentuk gas yang terutama terdiri dari metana (CH4). Gas ini dapat ditemukan di ladang minyak, ladang gas bumi dan juga tambang batu bara (Speight, 2007). Selain dari metana sebagai kandungan utama dari gas alam, kandungan hidrokarbon lainnya antara lain ethana, propana dan butana. Kandungan diluar kategori hidrokarbon adalah nitrogen, karbon dioksida dan hidrogen sulfida dan sedikit argon, karbon dan helium. Komposisi yang ada pada gas alam memiliki varian yang sangat luas. Gas alam dapat juga memiliki kandungan hidrokarbon C5+.

\section{Baja Tahan Karat Austenitik}

Baja tahan karat austenitik merupakan merupakan bagian terbesar dari kelompok baja tahan karat (Stainless Steel) paduan tinggi berdasarkan pada sistem $\mathrm{Fe}-\mathrm{Cr}$, Fe-Cr-C, dan Fe$\mathrm{Cr}-\mathrm{Ni}$ dilihat dari jumlah variasi paduan dan penggunaannya. Baja tahan karat mengandung unsur paduan krom (Cr) minimal sekitar 11\%, kandungan ini dibutuhkan untuk mencegah terbentuknya karat pada udara yang tidak terpolusi (sehingga dinamakan tahan karat). 
Unsur lain yang ditambahkan untuk menambah sifat-sifat tertentu dari baja tahan karat adalah nikel (Ni), molybdenum (Mo), tembaga (Cu), titanium (Ti), aluminium (Al), silikon (Si), noibium (Nb), nitrogen (Ni), sulfur (S) dan selenium (Se). Jumlah kandungan karbon biasanya kurang dari 0,03\% dan lebih dari 1.0\%.

Baja tahan karat austenitik, sesuai dengan namanya didominasi oleh fase struktur mikro austenite pada temperatur kamar, tidak dapat diperkeras oleh pengerjaan panas, memiliki sifat non magnetik dengan struktur mikro face centered cubic (fcc) dan mampu menanggung temperatur tinggi (900oC hingga 1400oC). Baja tahan karat austenitik juga memiliki keuletan, kemampubentukan, dan ketangguhan yang sangat baik bahkan pada temperatur kriogenik. Sebagai tambahan, pada dasarnya baja tahan karat jenis ini dapat mengeras pada pengerjaan dingin (Davis J. , 1994). Kelebihan lain dari baja tahan karat austenitic dibandingkan baja tahan karat jenis lain adalah mempunyai sifat ketahanan korosi dan mampu las yang lebih baik (Lippold \& Kotecki, 2005).

\section{Grade 321}

Baja tahan karat austenitic grade 321 merupakan salah satu kategori dari baja tahan karat austenitik. Penamaan grade 321 menggunakan Unified Numbering System (UNS) adalah grade S32100. Grade 321 merupakan grade basis baja tahan karat austenitik (grade 304) yang ditambahkan unsur titanium. Grade 321 menurut ASTM A240 diharuskan memiliki komposisi kimia C maksimum 0,08\%; Mn maksimum 2 \%; $\mathrm{P}$ maksimum 0,045\%; S maksimum 0,03\%; Si maksimum 0,75\%; Cr 17 19\%; Ni 9-12\% ; N 0,1\%. Titanium dengan kandungan tidak boleh kurang dari 5 kali kandungan karbon ditambah nitrogen dan tidak boleh lebih dari $0,7 \%$. Sifat mekanik yang harus dipenuhi untuk memenuhi spesifikasi ini adalah kekuatan tarik minimum 75 ksi (515 Mpa); kekuatan luluh minimum 30 ksi (205 Mpa); Elongasi minimum dalam panjang 2 inci atau 50 mm sebesar $40 \%$; Kekerasan maksimum 40 skala brinell atau 95 skala Rockwell B (Davis J. , 1994).

\subsection{Metalurgi Pengelasan}

Pada saat proses pengelasan, beberapa perubahan timbul yang dapat mempengaruhi perilaku pengelasan pada hasil lasan. Studi metalografi menunjukan beberapa daerah terbentuk pada hasil lasan. Wilayah komposit (composite region) atau daerah fusi pada dasarnya terdiri dari logam pengisi yang telah melebur dengan base metal. Daerah disekitar wilayah komposit adalah unmixed zone yaitu daerah yang logam dasar melebur dan dengan cepat memadat membentuk komposisi logam yang sama dengan base metal. Weld interface merupakan wilayah terjadinya peleburan sempurna terjadi selama pengelasan dan dibuktikan dengan adanya struktur coran. Partialy melted zone merupakan wilayah terjadinya peleburan antara $0 \%$ sampai $100 \%$ dan terakhir adalah true HAZ adalah daerah terpapar panas pada base metal yang mengakibatkan terjadinya perubahan pada struktur mikro tanpa terjadinya peleburan (Corrosion of Stainless Steel Weldments, 2003). Gambar 2.1 memberikan ilustrasi wilayah dari pengelasan fusi.

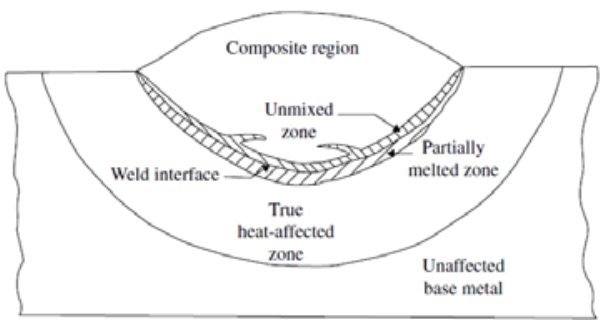

Gambar 2.1 Wilayah dari las fusi

Beberapa kemungkinan metalurgi yang terjadi selama pengelasan adalah sebagai berikut (Corrosion of Stainless Steel Weldments, 2003):

1. Presipitasi intergranular, M23C6 yang kaya kromium, kromium karbida didalam HAZ, yang dapat menyebabkan kerentanan terhadap korosi.

2. Transformasi lasan dari ferit - fase sigma selama temperatur elevated.

\subsubsection{Presipitat (endapan)}

Pada keadaan setimbang, baja tahan karat austenitik sepenuhnya berbentuk austenit dalam proses pendinginan sampai temperatur kamar. Ketika HAZ dipanaskan sampai temperatur mendekati temperatur solidus paduan, berbagai presipitat yang terdapat dalam Base Metal terlarut. Hal tersebut akan mendorong kepada super saturasi matriks austenit selama pendinginan.

Karbida merupakan presipitat yang paling banyak terbentuk dalam HAZ pada baja tahan karat austenitik. Bermacam-macam presipitat juga dapat hadir dalam baja tahan karat austenitik, bergantung pada komposisi dan perlakuan panas. Ditemukan hasil-hasil transformasi yang terdiri dari berbagai fasa inter metalik dan karbida M23C6. Fase sigma, chi, eta, G dan laves juga terbentuk dalam baja tahan karat austenitik, khususnya dalam kondisi penambahan Mo, Nb, dan Ti. Fasa-fasa tersebut terbentuk pada waktu paparan yang sangat lama pada temperatur yang semakin tinggi. Daftar jenisjenis presipitat, struktur dan stoikiometrinya ditunjukkan dalam Tabel 2.1. 
Tabel 2.1 Jenis-Jenis Presipitat dalam Baja Tahan Karat Austenitik (Lippold \& Kotecki, 2005)

\begin{tabular}{|c|c|c|c|}
\hline $\begin{array}{l}\text { Endapan } \\
\text { (Preticipate) }\end{array}$ & $\begin{array}{l}\text { Struktur } \\
\text { Kristal }\end{array}$ & $\begin{array}{l}\text { Parameter kisi } \\
\text { (Lattice } \\
\text { Parameter) }\end{array}$ & Stoikiometri \\
\hline $\mathrm{MC}$ & FCC & $\mathrm{a}=0,424-0,447$ & TiC, $\mathrm{NbC}$ \\
\hline $\mathrm{M}_{6} \mathrm{C}$ & $\begin{array}{l}\text { Diamond } \\
\text { cubic }\end{array}$ & $a=1,062-1,128$ & $\begin{array}{l}(\mathrm{FeCr})_{3}, \mathrm{Mo}_{3} \mathrm{C}, \\
\mathrm{Fe}_{3} \mathrm{Nb}_{3} \mathrm{C}, \\
\mathrm{Mo}_{5} \mathrm{SoC}\end{array}$ \\
\hline $\mathrm{M}_{23} \mathrm{C}_{6}$ & FCC & $a=1,057-1,068$ & $\begin{array}{l}(\mathrm{Cr}, \mathrm{Fe})_{23} \mathrm{C}_{6}, \\
(\mathrm{Cr}, \mathrm{Fe}, \mathrm{Mo})_{23} \mathrm{C}_{6}\end{array}$ \\
\hline $\mathrm{NbN}$ & FCC & $\mathrm{a}=0,440$ & $\mathrm{NbN}$ \\
\hline $\mathrm{Z}$ phase & Tetragonal & $\begin{array}{l}a=0,307, c= \\
0,7391\end{array}$ & $\mathrm{CrNbN}$ \\
\hline $\begin{array}{l}\text { Sigma phase } \\
(\sigma)\end{array}$ & Tetragonal & $\begin{array}{l}a=0,880, c= \\
0,454\end{array}$ & Fe-Ni-Cr-Mo \\
\hline $\begin{array}{l}\text { Laves phase } \\
(\eta)\end{array}$ & Hexagonal & $\begin{array}{l}a=0,473, c= \\
0,772\end{array}$ & $\mathrm{Fe}_{2} \mathrm{Mo}, \mathrm{Fe}_{2} \mathrm{Nb}$ \\
\hline Chi phase & BCC & $\begin{array}{l}\mathrm{a}=0,8807- \\
0.2272\end{array}$ & $\mathrm{Fe}_{36} \mathrm{Cr}_{12} \mathrm{Mo}_{10}$ \\
\hline G phase & FCC & $\mathrm{a}=1.12$ & $\begin{array}{l}\mathrm{Ni}_{16} \mathrm{Nb}_{6} \mathrm{Si}_{7}, \\
\mathrm{Ni}_{16} \mathrm{Ti}_{6} \mathrm{Si}_{7}\end{array}$ \\
\hline \multirow[t]{2}{*}{$\mathrm{R}$} & Hexagonal & $\begin{array}{l}\mathrm{a}=1,0903, \mathrm{c}= \\
1,9342\end{array}$ & Mo-Co-Cr \\
\hline & Rhobohedral & $\begin{array}{l}\mathrm{a}=0,9011, \alpha= \\
74^{\circ} 27,5^{\prime}\end{array}$ & Mo-Co-Cr \\
\hline $\begin{array}{l}\varepsilon \text { Nitride } \\
\left(\mathrm{Cr}_{2} \mathrm{~N}\right)\end{array}$ & Hexagonal & $\begin{array}{l}a=0,480, c= \\
0,447\end{array}$ & $\mathrm{Cr}_{2} \mathrm{~N}$ \\
\hline $\mathrm{Ni}_{3} \mathrm{Ti}$ & Hexagonal & $\begin{array}{l}a=0,9654, c= \\
1,5683\end{array}$ & $\mathrm{Ni}_{3} \mathrm{Ti}$ \\
\hline $\mathrm{Ni}_{3}(\mathrm{Al}, \mathrm{Ti})$ & FCC & $\mathrm{a}=0,681$ & $\mathrm{Ni}_{3} \mathrm{Al}$ \\
\hline
\end{tabular}

\subsubsection{Reaksi Solidifikasi}

Struktur mikro akhir lasan dikontrol oleh perilaku solidifikasi dan transformasi keadaan padat, skematik perilaku solidifikasi dan transformasi keadaan padat ditunjukan pada Gambar 2.3 dan gambar Light optical photomicrograph ditunjukan pada Gambar 2.3 Terdapat 4 kemungkinan solidifikasi dan transformasi keadaan padat pada logam las baja tahan karat austenitik seperti yang ditunjukkan pada Tabel 2.2. dan hubungannya dengan dengan diagram fasa Pseudobiner digambarkan pada Gambar 2.4.

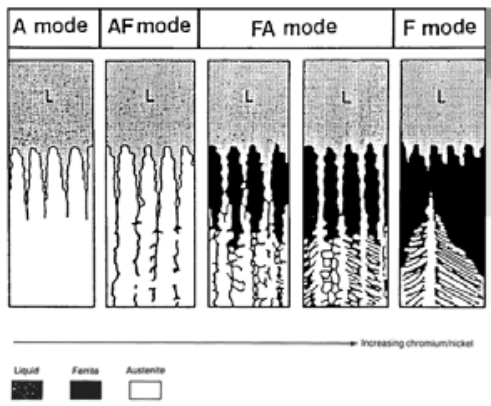

Gambar 2.3 Skematik Perilaku Solidifikasi dan Transformasi Keadaan Padat pada Lasan dengan Peningkatan Rasio $\mathrm{Cr}_{\mathrm{eq}} / \mathrm{Ni}_{\mathrm{eq}}$

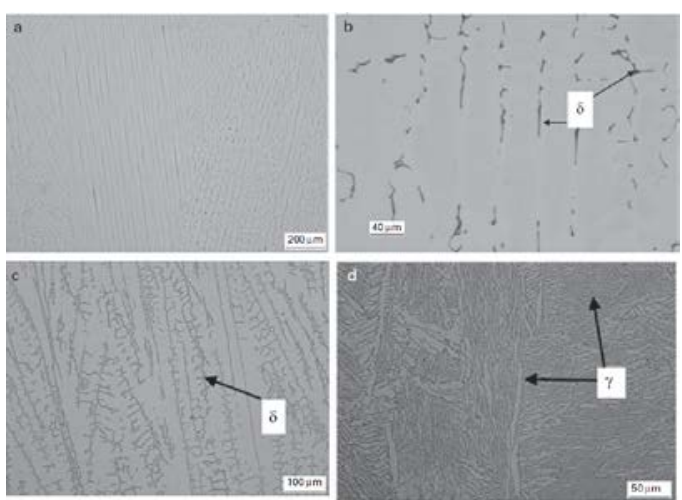

Gambar 2.4 Light optical photomicrograph dari struktur mikro baja tahan karat austenitic dalam beberapa kondisi solidfikasi: (a) solidfikasi A, (b) solidfikasi AF, (c) solidfikasi FA, (d) solidfikasi F

Tabel 2.2 Tipe Solidifikasi, Reaksi dan Struktur Mikro (Lippold \& Kotecki, 2005)

\begin{tabular}{|l|l|l|}
\hline Jenis Solidifikasi & Reaksi & Struktur Mikro \\
\hline $\mathrm{A}$ & $\mathrm{L} \rightarrow \mathrm{L}+\mathrm{A} \rightarrow \mathrm{A}$ & $\begin{array}{l}\text { Fully austenitic, well } \\
\text { defined solidification } \\
\text { structure }\end{array}$ \\
\hline $\mathrm{AF}$ & $\begin{array}{l}\mathrm{L} \rightarrow \mathrm{L}+\mathrm{A} \rightarrow \mathrm{L}+ \\
\mathrm{A}+(\mathrm{A}+\mathrm{F})_{\mathrm{eut}} \rightarrow \mathrm{A} \\
+\mathrm{F} \text { eut }\end{array}$ & $\begin{array}{l}\text { Ferrite at cell and } \\
\text { dendrite boundaries }\end{array}$ \\
\hline $\mathrm{FA} \rightarrow \mathrm{L}+\mathrm{F} \rightarrow \mathrm{L}+$ & $\begin{array}{l}\text { Skeletal and/or lathy } \\
\text { ferrite resulting from } \\
\text { ferrite-to-austenite } \\
\text { transformation }\end{array}$ \\
\hline $\mathrm{F}+\mathrm{A}+\mathrm{A})_{\mathrm{per} / \mathrm{eut}} \rightarrow$ & $\begin{array}{l}\mathrm{L} \rightarrow \mathrm{L}+\mathrm{F} \rightarrow \mathrm{F} \rightarrow \\
\mathrm{F}+\mathrm{A}\end{array}$ & $\begin{array}{l}\text { Acicular ferrite or } \\
\text { ferrite matrix } \text { with } \\
\text { grain boundary } \\
\text { austenite and } \\
\text { widmanstatten side } \\
\text { plates }\end{array}$ \\
\hline
\end{tabular}

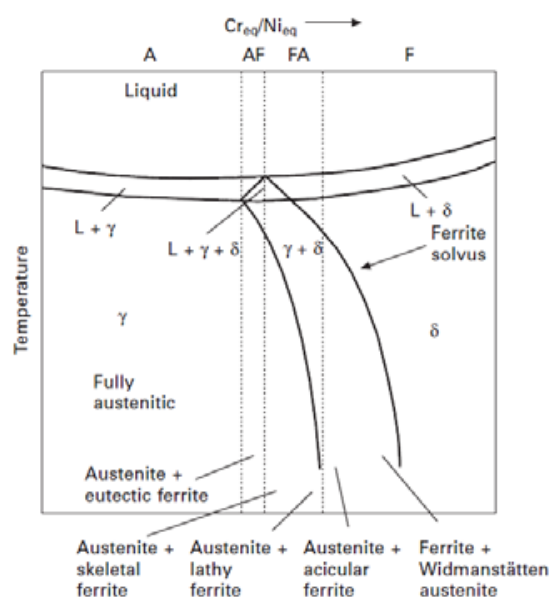

Gambar 2.4 Hubungan Tipe Solidifikasi dengan Diagram Fasa Pseudobiner

\section{Karbida $\mathbf{M}_{23} \mathrm{C}_{6}$}

Karbida terdapat dalam setiap baja tahan karat austenitik, karena kromium merupakan pembentuk kuat karbida. Penambahan beberapa pembentuk karbida, seperti Mo, Nb, Ti juga mendukung pembentukan karbida. 
Presipitasi karbida M23C6 memiliki pengaruh terhadap ketahanan korosi. Presipitat karbida tumbuh cepat di sepanjang batas butir pada temperatur $700-900^{\circ} \mathrm{C}$ dan paling banyak terbentuk dalam HAZ pada baja tahan karat austenitik. Pada umumnya presipitat karbida tumbuh di sepanjang batas butir atau interface ferit - austenite [6].

Karbida ini biasanya terdapat pada baja tahan karat yang diberi perlakuan panas dan biasanya terbentuk sebelum fasa intermetalik. Hal ini disebabkan sifat difusi yang cepat dari atom C. Karbida M23C6 membentuk inti dan tumbuh kedalam matriks ferit. Pada pemanasan $700{ }^{\circ} \mathrm{C}$ pengendapan M23C6 dalam austenite terbatas. Hal ini menunjukkan bahwa larutan lewat jenuh karbon dalam ferit lebih kecil daripada dalam austenit.

\section{Sigma Phase $(\sigma)$}

Pada Base Metal dan logam las baja tahan karat austenitik sangat rentan terhadap pembentukan fasa sigma. fasa sigma dapat terbentuk dalam berbagai jenis baja tahan karat, tetapi paling umum cenderung terjadi dalam kadar $\mathrm{Cr}$ yang tinggi pada austenitik, feritik, dan paduan duplex.

Pembentukan fasa sigma bergeser ke kandungan $\mathrm{Cr}$ yang lebih rendah dan temperatur yang lebih tinggi. Nikel dapat meningkatkan interval temperatur pembentukan fasa sigma dari 815-926 ${ }^{\circ} \mathrm{C}$, tetapi pengaruh nikel dalam meningkatkan pembentukan fasa sigma tidak seefektif $\mathrm{Mn}$ atau unsur-unsur kuat pembentuk ferit seperti Mo, S dan Al.

\section{Fasa Chi $(\chi)$}

Fasa chi adalah suatu senyawa intermetalik stabil yang mengandung $\mathrm{Fe}, \mathrm{Cr}$ dan Mo. Secara teoritis fasa chi dapat merupakan suatu senyawa pelarut karbon dengan tipe $\mathrm{M}_{18} \mathrm{C}$. Komposisi fase chi bervariasi dengan toleransi yang tinggi, sehingga sulit dibedakan dengan fasa sigma melalui metoda EDX. Dengan penambahan karbon perbandingan unsur dalam fasa chi bergeser kearah Mo, yang mana berarti bergeser ke arah pembentukan karbida kuat.

\section{Fasa R}

Fasa $\mathrm{R}$ mempunyai struktur hexagonal dengan jarak antar kisi yang cukup lebar. Fasa R adalah fasa intermetalik Fe, $\mathrm{Cr}$ dan Mo yang mirip dengan fasa sigma dan chi. Dyson dan Keown membahas pergerakan atomic dalam ferit untuk mengakomodasikan struktur fasa R. Ditemukan bahwa hanya sedikitr pergerakan atom kecil dan pergerakan kisi dibutuhkan untuk terbentuknya fasa $\mathrm{R}$ dari ferit. Secara teoritis transformasi delta ferit menjadi fasa $\mathrm{R}$ lebih mudah dibandingkan dengan fasa sigma.

\subsection{Perilaku Korosi Cacat Retak pada Baja Tahan Karat}

Proses korosi cacat retak pada baja tahan karat adalah hot cracking, Cold cracking, stress corrosion cracking, sigma phase embritllement.

\subsubsection{Hot Cracking}

Hot cracking terbentuk pada saat temperatur lasan yang tinggi dan biasanya berhubungan dengan solidfikasi. Hot cracking yang muncul selama pendinginan dekat dengan temperatur solidus memiliki karakterisitik intergranular cracking. Jenis dari hot cracking adalah solidification cracking, liquation cracking, ductility dip cracking dan reheat cracking. Crack biasanya timbul pada logam lasan atau HAZ base metal.

Kerentanan hot cracking pada baja tahan karat ditentukan oleh pola solidfikasi dan sejumlah unsur pengotor. Pola solidfikasi utama sangat dikendalikan oleh komposisi. Paduan yang memperkuat dalam modus FA yang paling tahan terhadap crack. Untuk mengevaluasi paduan tertentu untuk kerentanan terhadap cracking, nilai lengkap

Nieq dan Creq yang diizinkan dalam spesifikasi harus diplot pada diagram. Beberapa paduan dapat menunjukkan variasi komposisi yang berada di dalam spesifikasi baik pola solidfikasi AF dan FA.

Kujanpaa dan Suutala dan rekan kerja telah mengembangkan sebuah diagram yang sangat berguna yang menyumbang kedua modus pemadatan dan kandungan pengotor $(\mathrm{P}+\mathrm{S})$ pada solidfication cracking pada baja tahan karat. Diagram ditunjukkan pada Gambar. 2.6 dan plot perilaku retak sebagai fungsi gabungan kandungan P + S dan rasio Creq / Nieq. Diagram ini dikembangkan melalui penelaahan dari berbagai studi solidfication cracking.

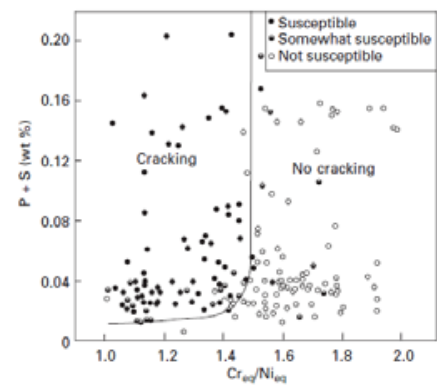

Gambar 2.5 Diagram Suutala

Nilai-nilai $\mathrm{C}_{\text {req }}$ dan $\mathrm{Ni}_{\mathrm{eq}}$ digunakan untuk Gambar 2.5 yang yang dikembangkan oleh Hammar dan Svenson adalah sebagai berikut:

$\mathrm{Cr}_{\text {eq }}$ $=\mathrm{Cr}+$

$1.37 \mathrm{Mo}+1.5 \mathrm{Si}+2 \mathrm{Nb}+3 \mathrm{Ti}$

$\mathrm{Ni}_{\text {eq }}=\mathrm{Ni}+0.31 \mathrm{Mn}+22 \mathrm{C}+14.2 \mathrm{~N}+\mathrm{Cu}(2.2)$

\subsubsection{Cold Cracking}

Cold cracking dapat muncul karena adanya

empat faktor secara simultan, yaitu sumber 
hidrogen, tegangan tarik sisa, temperatur dibawah $200^{\circ} \mathrm{C}$, dan struktur mikro yang rentan. Tiga faktor pertama akan selalu muncul pada pengerjaan pengelasan, sedangkan pada faktor terakhir pada dasarnya adalah struktur mikro martensit yang keras dan getas (Singh, 2009).

Cold cracking dapat ditemukan pada HAZ atau logam lasan tergantung kepada tipe baja yang dilas. Hidrogen dapat masuk kedalam busur lasan dari berbagai sumber termasuk uap lembab pada pelat atau di dalam udara, cat atau minyak pada plat dan lainnya. Hidrogen mudah larut dalam larutan pada logam las cair dan tetap dalam larutan pada saat solidfikasi ke dalam delta ferrit ataupun austenite.

Karakteristik dari cold cracking dapat dilihat sebagai berikut:

1. Kontaminasi hidrogen pada struktur lasan

2. Adanya tegangan tarik

3. Fenomena crack biasanya timbul seminggu atau bahkan satu bulan setelah pengelasan

4. Retak bisa berbentuk intergranular atau transgranular

5. Orientasi pada root atau toe hampir seluruhnya tegak lurus dari permukaan base metal dan parallel ke axis lasan.

\subsubsection{Stress Corrosion Cracking}

Stress corrosion cracking pada baja tahan karat dapat muncul pada saat paduan terkena tegangan tarik dan media korosi tertentu secara simultan. Variabel penting yang mempengaruhi timbulnya SCC adalah temperatur, lingkungan, komposisi material, tingkatan stress dan struktur mikro. Penyebaran crack bisa transgranular atau intergranular, tergantung dari interaksi setiap variabel. Intergranular stress corrosion cracking dapat timbul meskipun paduan tidak sensitif terhadap korosi intergranular. Adanya tegangan tarik sisa pada daerah HAZ dapat mempercepat terjadinya korosi, terutama sensitasi sepanjang batas butir (Davis J. R., 2006). Cacat retak biasanya muncul pada temperatur logam diatas $140^{\circ} \mathrm{C}$ (API RP 571 Damage Mechanisms Affecting Fixed Equipment in Refining Industry, 2011).

Bentuk retak transgranular biasanya timbul pada lingkungan yang mengandung chloride, tetapi juga dapat terjadi di media kaustik. Ion-ion dari keluarga halogen (fluor, klor, bromin dan iodin) menjadi pendorong timbulnya transgranular SCC. Dari halida, ion klorida merupakan penyebab terbesar timbulnya kegagalan. Gambar 2.6 menunjukan contoh dari transgranular SCC pada baja tahan karat tipe 316L, crack dimulai dari kaki (toe) lasan, mungkin karena tingkat tegangan sisa yang tinggi pada lokasi tersebut (Davis J. R., 2006).

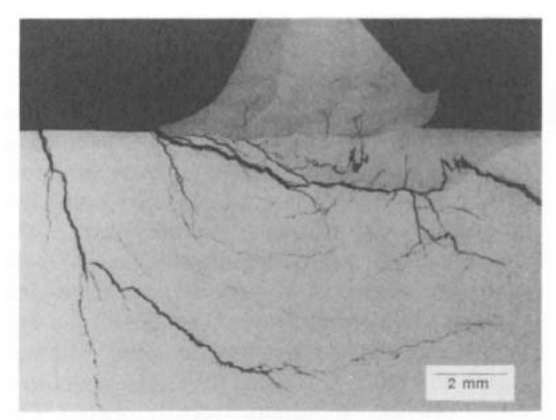

Gambar 2.6 Transgranular SCC yang dimulai dekat kaki lasan pada tipe paduan 316L

Kandungan nikel pada paduan memiliki pengaruh besar terhadap resistensi. Kerentanan terhadap korosi terbesar adalah pada nikel isi 8\% sampai $12 \%$. Paduan dengan isi Nikel di atas 35\% sangat tahan terhadap korosi dan kandungan Nikel didalam paduan di atas $45 \%$ kebal terhadap korosi. Sedangkan kadar nikel yang lebih rendeah meningkatkan resistensi untuk baja tahan karat seri 300 tetapi tidak membuat tahan.

\subsubsection{Sigma phase embrittlement}

Sigma phase embrittlement merupakan perubahan metalurgi yang tidak langsung muncul dan hanya bisa diketahui melalui pengamatan metalografi dan pengujian impak. Kerusakan akibat dari Sigma phase embrittlement muncul dalam bentuk retak terutama di daerah lasan.

Kerentanan logam lasan pada sigma phase embrittlement dari baja tahan karat austenitic pada suhu diatas $550^{\circ} \mathrm{C}$ tergantung pada kandungan delta ferrit: delta ferrit $<3$ FN kerentanan terhada kegetasan rendah, karena kandungan sigma phase $<3 \%$; Delta ferrit antara 3 dan 8 FN, kerentanan terhadap kegetasan menengah karena kandungan sigma phase antara 3\% dan 6\%; Delta ferrit $>8$ FN kerentanan terhadap embrittlement tinggi karena memiliki konten sigma phase $>6 \%$ (Handbook of Mechanical Alloy Design, 2004).

Ferrite number adalah deskripsi dari kandungan ferrit dari logam las yang ditentukan menggunakan prosedur dalam suatu standar. Ferrite Number dalam logam las dianggap kurang lebih setara dengan kandungan presentase ferrit (ISO 8249:2000 Welding — Determination of Ferrite Number (FN) in austenitic and duplex ferriticaustenitic Cr-Ni stainless steel weld metals, 2000). Perhitungan ferrit number dapat menggunakan Modified Schaefer-deLong Diagram atau magne gage.

Formula yang digunakan untuk perhitungan Ferrit Number dengan menggunakan Diagram Modified Schaefer-deLong adalah

$$
\begin{array}{ll}
\mathrm{Cr}_{\mathrm{eq}} & =1.5 \mathrm{Si}+ \\
\mathrm{Cr}+\mathrm{Mo}+2 \mathrm{Ti}+0.5 \mathrm{Nb} & \text { (2.3) }
\end{array}
$$


$\mathrm{Ni}_{\mathrm{eq}}=$

$F N=3.34 \mathrm{Cr}_{\text {eq }}-2.46 \mathrm{Ni}_{\text {eq }}-28.6$

Sedangkan dengan menggunakan magne gage dapat menggunakan Tabel 2.3 konversi old Mckay\% ferrite ke WRC ferrite Number (FN)

Tabel 2.3 Konversi Old McKay\% Ferit ke WRC Ferrite Number (Long \& DeLong, 1973)

\begin{tabular}{|c|c|}
\hline \multicolumn{2}{|c|}{$\begin{array}{l}\text { Table } 1 \text { - Conversion - Old McKay \% } \\
\text { Ferrite (as measured with a Magne-Gage) } \\
\text { to WRC Ferrite Number (FN) }\end{array}$} \\
\hline $\begin{array}{l}\text { Old } \\
\% F\end{array}$ & $\begin{array}{l}\text { New } \\
\text { FN }\end{array}$ \\
\hline Up to 6.0 & Same as old \% \\
\hline 7.0 & 7.2 \\
\hline 8.0 & 8.5 \\
\hline 9.0 & 9.8 \\
\hline 10.0 & 11.1 \\
\hline 11.0 & 12.4 \\
\hline 12.0 & 13.7 \\
\hline 13.0 & 15.0 \\
\hline 14.0 & 16.2 \\
\hline
\end{tabular}

\section{METODE PENELITIAN}

Langkah-langkah penelitian yang dilakukan terhadap sampel spool pipa venting system pre air cooler adalah sebagai berikut:

Pengambilan Sampel dan data lapangan, dan Pengujian yaitu Pengamatan visual, pengujian komposisi kimia, pengujian kekerasan, pengamatan makrofotografi dan mikrofotografi, pengamatan metallografi, pengujian microhardness, pengamatan fraktografi, dan analisis mikro dengan EDS.

\section{HASIL DAN PEMBAHASAN}

\section{Pengambilan Sampel dan data lapangan}

Analisa Chromatography dari CPU Gas

Flowboss didapatkan:

$$
\text { Tekanan (bar) : } 53.8
$$

Temperatur $\left({ }^{\circ} \mathrm{C}\right) \quad: 39.2$

Laju alir (mmscfd) : 575

Kandungan kimia yang dilayani oleh pre air cooler ditunjukan pada table 4.1

Tabel 4.1 Kandungan Kimia Gas (\%mol)

\begin{tabular}{|l|l|}
\hline \multicolumn{1}{|c|}{ Nama } & \multicolumn{2}{c|}{$\% \mathrm{~mol}$} \\
\hline Carbon dioksida (CO2) & 4.573 \\
\hline Nitrogen (N2) & 0.075 \\
\hline Methane (C1) & 86.590 \\
\hline Ethane (C2) & 3.629 \\
\hline Propane (C3) & 2.770 \\
\hline iso-Buthane (i-C4) & 0.636 \\
\hline normal Buthane (n-C4) & 0.667 \\
\hline iso-Pentane (i-C5) & 0.280 \\
\hline normal Pentane (n-C5) & 0.164 \\
\hline Hexane plus (C6+) & 0.616 \\
\hline
\end{tabular}

Hasil data lapangan menunjukan termperatur operasi yang lebih rendah dari $60^{\circ} \mathrm{C}$ dan tidak ditemukannya kandungan klorida di dalam fluida yang dilayani. Dari hasil data lapangan, terjadinya SCC akibat faktor lingkungan tidak ada. Sulfur yang dapat membentuk asam sulfida sebagai pemicu korosi lainnya juga tidak ditemukan.

\subsection{Pengamatan Visual}

Sampel yang diterima adalah komponen pipe spool bagian dari sistem vent dengan sambungan las pada kedua leher flange. Lokasi terjadinya kebocoran diberi tanda. Sampel yang diterima diperlihatkan pada Gambar 4.1.

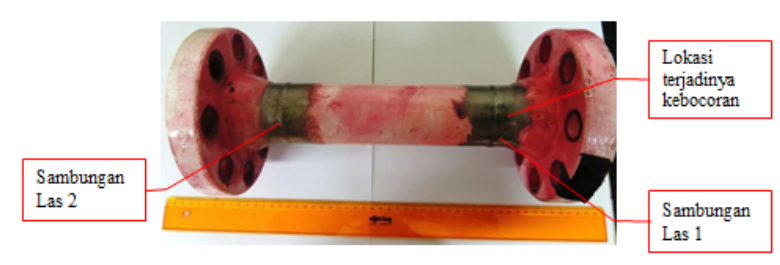

Gambar 4.1 Pipe spool

Untuk mengetahui lokasi kebocoran yang lebih akurat dilakukan kembali pengujian dye penetrant pada bagian sambungan las 1 . Flange sebelumnya dipotong untuk melakukan observasi pada bagian dalam. Setelah dilakukan pengujian dye penetrant, crack pada lasan dapat dilihat dengan jelas pada Gambar 4.2. dan Gambar 4.3. Crack pada permukaan bagian luar terlihat lebih pendek dari pada crack bagian dalam.

Daerah ini sepertinya tempat dimulainya pengelasan root dan ditemukan dalam kondisi underfill, ada kemungkinan sebelumnya merupakan lokasi tack weld yang telah dihilangkan atau dilas ulang. Terbentuknya crack pada lasan terdapat pada daerah batas antara logam lasan dan base metal. Berdasarkan lokasinya, cacat lasan disebut toe crack, root crack atau underbead crack.

Magnet juga dicoba dilekatkan pada base metal dan daerah logam lasan, Hasil observasi pada base metal pada flange dan pipa merupakan material non magnetik. Akan tetapi magnet menempel pada bagian logam lasan sepeti yang ditunjukan pada Gambar 4.4.
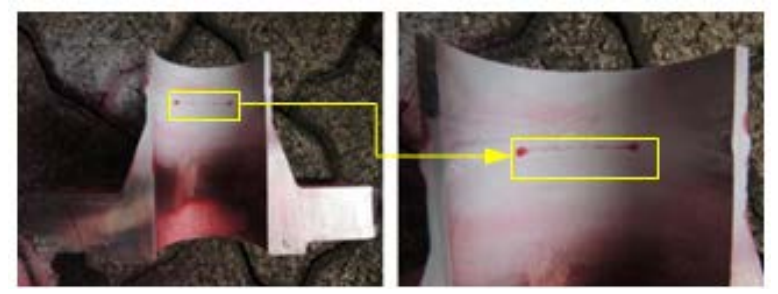

Gambar 4.2 Crack yang terlihat pada bagian dalam pipe spool pada sambungan las 1 setelah pengujian dye penetrant 

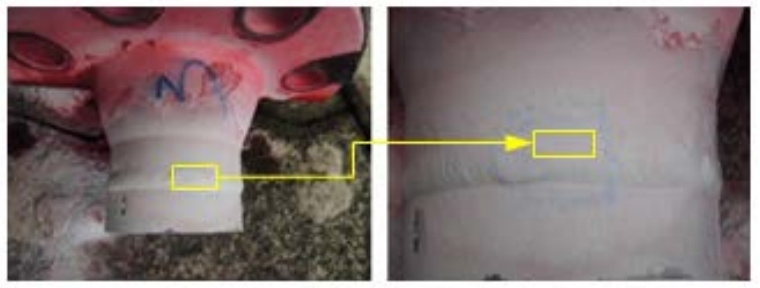

Gambar 4.3 Crack yang terlihat pada bagian luar pipa pada sambungan las 1 setelah pengujian dye penetrant

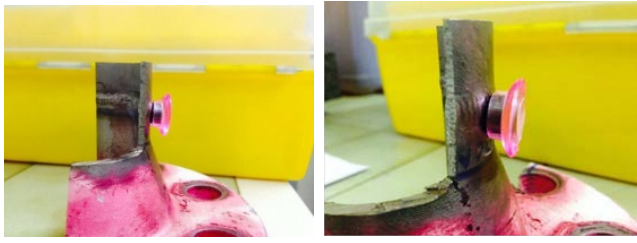

Gambar 4.4 Hasil observasi dari pelekatan magnet pada logam lasan

\subsection{Pengujian komposisi kimia}

Hasil pengujian komposisi kimia menggunakan Optical Emission Spectography dilakukan pada kedua flange, pipa dan logam lasan yang mengalami kebocoran. Hasil dari pengujian terlihat pada Tabel 4.2.

Tabel 4.2 Hasil Pengujian kimia spectography

\begin{tabular}{|c|c|c|c|c|c|c|c|c|c|}
\hline Part & $\begin{array}{l}\text { Sam } \\
\text { pel }\end{array}$ & C & $\begin{array}{l}\mathbf{M} \\
\mathbf{n}\end{array}$ & $\mathrm{Si}$ & $\mathbf{C r}$ & $\mathrm{Ni}$ & $\mathbf{P}$ & S & $\mathbf{T i}$ \\
\hline \multirow{2}{*}{$\begin{array}{l}\text { Flange } \\
\text { Upstrea } \\
\mathrm{m}\end{array}$} & 1 & $\begin{array}{l}0,0 \\
45\end{array}$ & $\begin{array}{l}1,6 \\
5\end{array}$ & $\begin{array}{l}0,5 \\
6\end{array}$ & $\begin{array}{l}\text { 16, } \\
7\end{array}$ & $\begin{array}{l}11 \\
, 1\end{array}$ & $\begin{array}{l}0,0 \\
47\end{array}$ & $\begin{array}{l}0,01 \\
4\end{array}$ & $\begin{array}{l}0,4 \\
4\end{array}$ \\
\hline & 2 & $\begin{array}{l}0,0 \\
36\end{array}$ & $\begin{array}{l}1,6 \\
7\end{array}$ & $\begin{array}{l}0,5 \\
3\end{array}$ & $\begin{array}{l}16, \\
6\end{array}$ & $\begin{array}{l}11 \\
, 1\end{array}$ & $\begin{array}{l}0,0 \\
45 \\
\end{array}$ & $\begin{array}{l}0,02 \\
4 \\
\end{array}$ & $\begin{array}{l}0,4 \\
1 \\
\end{array}$ \\
\hline \multirow{2}{*}{$\begin{array}{l}\text { Tube/Pi } \\
\text { pa }\end{array}$} & 3 & $\begin{array}{l}0,0 \\
45\end{array}$ & $\begin{array}{l}1,8 \\
6\end{array}$ & $\begin{array}{l}0,4 \\
7\end{array}$ & $\begin{array}{l}17, \\
5\end{array}$ & $\begin{array}{l}11 \\
, 5\end{array}$ & $\begin{array}{l}0,0 \\
20\end{array}$ & $\begin{array}{l}<0,0 \\
05\end{array}$ & $\begin{array}{l}0,2 \\
7\end{array}$ \\
\hline & 4 & $\begin{array}{l}0,0 \\
40\end{array}$ & $\begin{array}{l}1,8 \\
6\end{array}$ & $\begin{array}{l}0,4 \\
6\end{array}$ & $\begin{array}{l}17, \\
2\end{array}$ & $\begin{array}{l}11 \\
7\end{array}$ & $\begin{array}{l}0,0 \\
30\end{array}$ & $\begin{array}{l}<0,0 \\
05\end{array}$ & $\begin{array}{l}0,2 \\
5 \\
\end{array}$ \\
\hline \multirow{2}{*}{$\begin{array}{l}\text { Flange } \\
\text { Downst } \\
\text { ream }\end{array}$} & 5 & $\begin{array}{l}0,0 \\
48 \\
\end{array}$ & $\begin{array}{l}1,6 \\
9\end{array}$ & $\begin{array}{l}0,5 \\
3\end{array}$ & $\begin{array}{l}16, \\
9\end{array}$ & $\begin{array}{l}11 \\
, 2\end{array}$ & $\begin{array}{l}0,0 \\
37\end{array}$ & $\begin{array}{l}0,01 \\
1\end{array}$ & $\begin{array}{l}0,4 \\
1 \\
\end{array}$ \\
\hline & 6 & $\begin{array}{l}0,0 \\
49\end{array}$ & $\begin{array}{l}1,6 \\
9\end{array}$ & $\begin{array}{l}0,5 \\
5\end{array}$ & $\begin{array}{l}16, \\
9\end{array}$ & $\begin{array}{l}11 \\
, 0\end{array}$ & $\begin{array}{l}0,0 \\
42 \\
\end{array}$ & $\begin{array}{l}0,01 \\
7 \\
\end{array}$ & $\begin{array}{l}0,4 \\
3 \\
\end{array}$ \\
\hline $\begin{array}{l}\text { Logam } \\
\text { Las }\end{array}$ & 7 & $\begin{array}{l}0,0 \\
80\end{array}$ & $\begin{array}{l}1,8 \\
2\end{array}$ & $\begin{array}{l}0,6 \\
8\end{array}$ & $\begin{array}{l}18, \\
2\end{array}$ & $\begin{array}{l}10 \\
, 5\end{array}$ & $\begin{array}{l}0,0 \\
19\end{array}$ & $\begin{array}{l}0,03 \\
6\end{array}$ & $\begin{array}{l}0,1 \\
1\end{array}$ \\
\hline \multicolumn{2}{|c|}{ UNS 32100} & $\begin{array}{l}0,0 \\
80\end{array}$ & $\begin{array}{l}2,0 \\
0\end{array}$ & $\begin{array}{l}1,0 \\
0\end{array}$ & $\begin{array}{l}17, \\
0- \\
19, \\
0\end{array}$ & $\begin{array}{l}9, \\
0- \\
12 \\
, 0\end{array}$ & $\begin{array}{l}0,0 \\
45\end{array}$ & $\begin{array}{l}0,03 \\
0\end{array}$ & $\begin{array}{l}5 \mathrm{x} \\
\% \mathrm{C} \\
\mathrm{min}\end{array}$ \\
\hline \multicolumn{2}{|l|}{ ER 347} & $\begin{array}{l}0,0 \\
80\end{array}$ & $\begin{array}{l}1,0 \\
0- \\
2,5 \\
0\end{array}$ & $\begin{array}{l}0,3 \\
0- \\
0,6 \\
5\end{array}$ & $\begin{array}{l}19, \\
0- \\
21, \\
5\end{array}$ & $\begin{array}{l}9, \\
0- \\
11 \\
0\end{array}$ & $\begin{array}{l}0,0 \\
30\end{array}$ & $\begin{array}{l}0,03 \\
0\end{array}$ & - \\
\hline
\end{tabular}

Komposisi kimia yang didapat dari pengujian spectography untuk memastikan komposisi kimia dari perangkat yang ada pada pipa spool. Pada daerah logam las yang mengalami cacat retak, komposisi kimia dibutuhkan untuk melakukan perhitungan kemungkinan terjadinya hot cracking dan kandungan di dalamnya untuk menganalisa kemungkinan terjadinya stress corrosion cracking.

Komposisi kimia dari material flange dan pipa setelah merujuk ke standar, sesuai dengan komposisi kimia dari bahan UNS S32100 (321). Sementara itu komposisi logam las sedikit di luar parameter dari ER 347. Unsur kromium (18.2) dibawah standar (minimal 19,0). Unsur sulfur
$(0,036)$ dan silikon $(0,68)$ yang sedikit melebihi masing-masing parameter 0.030 untuk sulfur dan 0,65 untuk silikon.

Komposisi las sedikit diluar parameter kemungkinan terjadi reaksi thermokimia dan elektrokimia pada proses pengelasan. Jumlah bertambah dan berkurangnya dari unsur paduan dipengaruhi oleh komposisi flux, elektroda, base metal dan kondisi proses pengelasan. Perubahan komposisi akibat reaksi thermokimia dan elektrokimia lebih besar terjadi pada kecepatan pengelasan yang lambat.

\subsection{Pengujian kekerasan}

Hasil dari pengujian kekerasan dapat dilihat pada Tabel 4.3.

Tabel 4.3 Hasil pengujian kekerasan

\begin{tabular}{|l|c|c|}
\hline \multicolumn{1}{|c|}{ Part } & $\begin{array}{c}\text { Code } \\
\text { Sampel }\end{array}$ & Hardness (HRB) \\
\hline Flange & A1 & 82 \\
\cline { 2 - 3 } Upstream & A2 & 87 \\
\hline \multirow{2}{*}{ Pipa/Tube } & A3 & 78 \\
\cline { 2 - 3 } & A4 & 77 \\
\hline Flange & A5 & 80 \\
\cline { 2 - 3 } Downstream & A6 & 79 \\
\hline UNS 32100 & & $95 \mathrm{Max}$ \\
\hline
\end{tabular}

Dari hasil pengujian kekerasan material pipa spool vent, dengan mengacu ke pada standard diketahui sesuai dengan nilai kekerasan material UNS S32100.

4.4. Pengamatan makrofotografi dan mikrofotografi

Hasil dari pengamatan makrofotografi dapat dilihat pada gambar berikut:
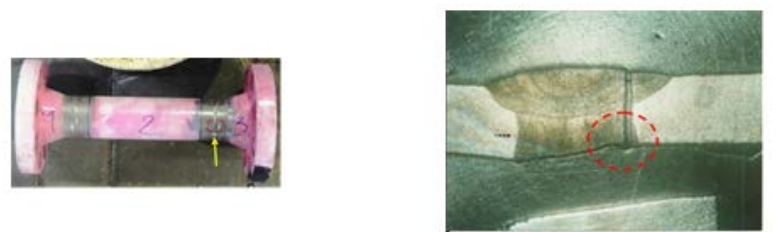

Gambar 4.5 Sambungan Las 1 yang terdapat crack, pembesaran 8 kali

Bentuk profil dari daerah yang diambil pada sambungan las 1 yang terdapat cacat retak (Gambar 4.5), memiliki profil cacat las underfill dengan takik lebih jelas terlihat, selain itu terlihat juga distorsi las. Cacat las ini dapat memancing dimulainya perambatan retakan yang ditimbulkan dari faktor konsentrasi stress.

\subsection{Pengamatan Metalografi}

Sampel diambil untuk pengamatan metalografi. Sampel yang diambil dari sambungan las antara flange dan pipa (weld neck). Persiapan dilakukan dengan penggrindaan, polis, dan electroetching. Beberapa titik diamati dibawah 
mikroskop optikal. Gambar 4.6 dan gambar 4.7 adalah hasil observasi dibawah mikroskop optikal.

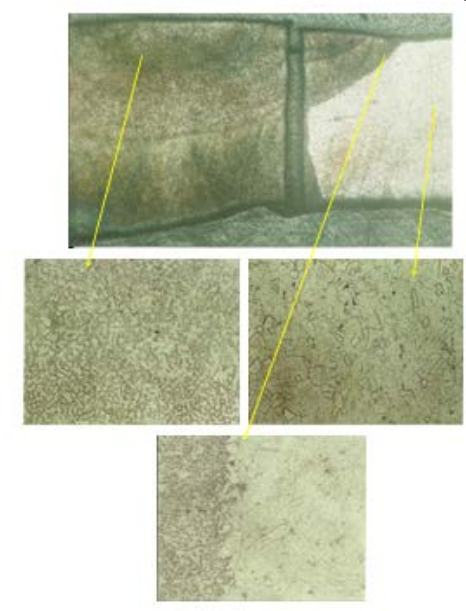

Gambar 4.6 Struktur mikro dari sambungan las $1 \mathrm{di}$ daerah yang terdapat cacat retak (pembesaran 200x)

Mikrostruktur umumnya untuk baja tahan karat austenitic pada base metal sementara pada logam lasan merupakan struktur dendritik sebagai akibat dari proses pengelasan (mirip dengan logam cor). Hal ini memperjelas penyebab menempelnya magnet pada lasan saat dilakukan pengamatan visual sebelumnya.

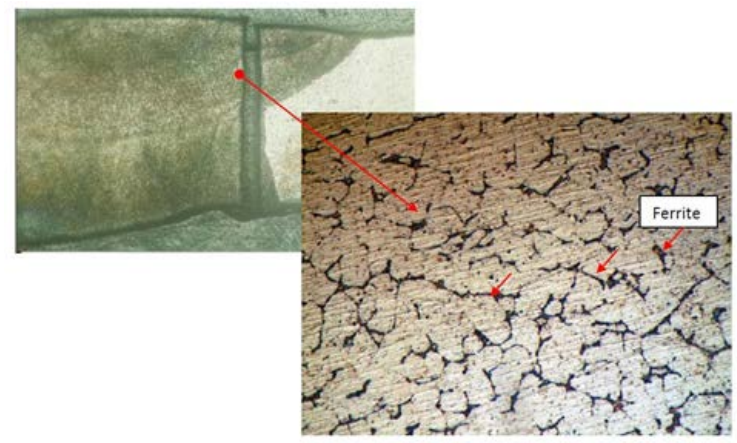

Gambar 4.7 Struktur mikro yang diambil pada bagian tepi dari retakan lasan (pembesaran 500x)

Mikrostruktur dari base metal merupakan campuran dari ferrite dan austenite. Hal ini mirip dengan mikrostruktur dari lasan baja tahan karat austenitik..

Kandungan ferit dalam logam lasan pada Gambar 4.8. dihitung dengan metode planimetri dan hasil dari image analyzer didapat besaran 10,5 \%.

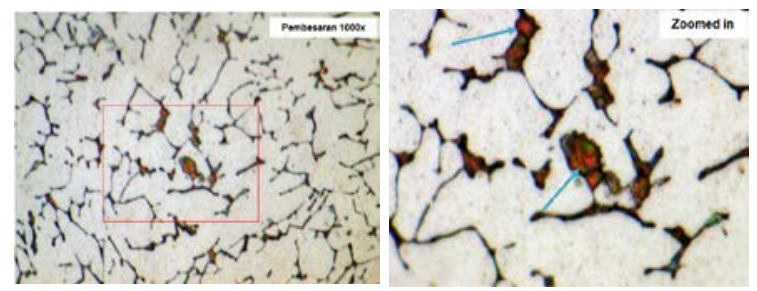

Gambar 4.5 Phase sigma terlihat pada daerah berwarna oranye/coklat
Phase Sigma diidentifikasi setelah pengerjaan electroetching menggunakan $\mathrm{NaOh}$. Daerah yang diduga merupakan phase sigma berwana oranye/coklat, sedangkan delta ferit berwana biru kehitaman/hitam.

\subsection{Pengujian Microhardness}

Daerah pengujian microhardness pada daerah sambungan lasan 1 tanpa kerusakan dapat dilihat pada gambar 4.9 dan hasilnya dapat dilihat pada tabel 4.4.

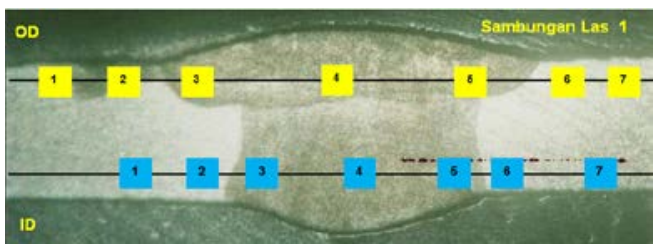

Gambar 4.9 Lokasi pengujian kekerasan mikro pada sambungan las 1

Tabel 4.4 Hasil pengujian kekerasan mikro pada sambungan las 1

\begin{tabular}{|c|c|c|c|}
\hline Kode Sampel & Kode daerah & Titik & HVN \\
\hline \multirow{14}{*}{ Sambungan Las 1} & \multirow{7}{*}{ Sisi Luar } & 1 & 108 \\
\hline & & 2 & 212 \\
\hline & & 3 & 461 \\
\hline & & 4 & 193 \\
\hline & & 5 & 304 \\
\hline & & 6 & 109 \\
\hline & & 7 & 191 \\
\hline & \multirow{7}{*}{ Sisi Dalam } & 1 & 107 \\
\hline & & 2 & 191 \\
\hline & & 3 & 212 \\
\hline & & 4 & 191 \\
\hline & & 5 & 187 \\
\hline & & 6 & 165 \\
\hline & & 7 & 103 \\
\hline
\end{tabular}

Hasil dari pengujian kekerasan mikro pada sambungan menunjukan adanya nilai yang fluktuatif tergantung dari kualitas permukaan dari sampel, akan tetapi beberapa nilai menunjukan struktur mikro yang berdekatan dengan daerah HAZ lebih keras.

Daerah yang berdekatan dengan retakan juga diperiksa. Gambar 4.10. menunjukan hasil dari pengujian mikro. Kekerasan rata-rata skala Vickers adalah sebagai berikut:

$$
\overline{H V}=\frac{186+191+167+158+160}{5}=172,4
$$

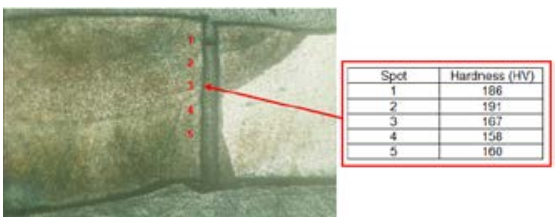

Gambar 4.10 Pengujian kekerasan mikro pada daerah yang dekat dengan cacat retak 


\subsection{Pengamatan Fraktografi}

Pengamatan fraktografi dilakukan dengan menggunakan Scanning Electron Microscope (SEM). Sampel untuk fraktografi diambil dari lokasi logam lasan dimana terjadi cacat retak. Retakan ini telah dibelah dengan proses pemotongan. Hasil pengamatan dapat dilihat pada Gambar 4.11.
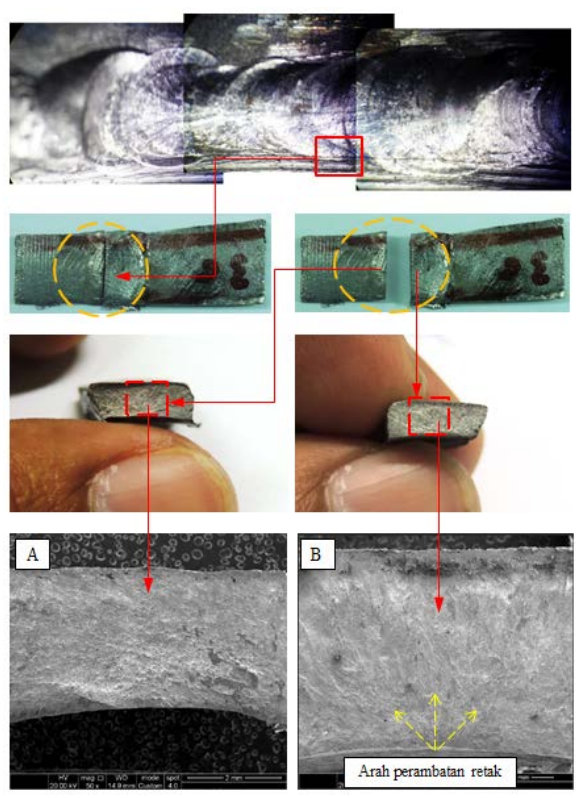

Gambar 4.11 Retak permukaan pada retakan logam lasan pada sambungan las 1 menunjukan adanya brittle fracture

Selanjutnya pengamatan pada permukaan retakan dilakukan dengan menggunakan pembesaran 5000 kali dengan hasil seperti pada Gambar 4.12, dan Gambar 4.13, menunjukan retak trangranular, juga ditemukan adanya pola getas dan inklusi, hal ini biasanya juga merupakan pertanda adanya fase sigma pada logam.
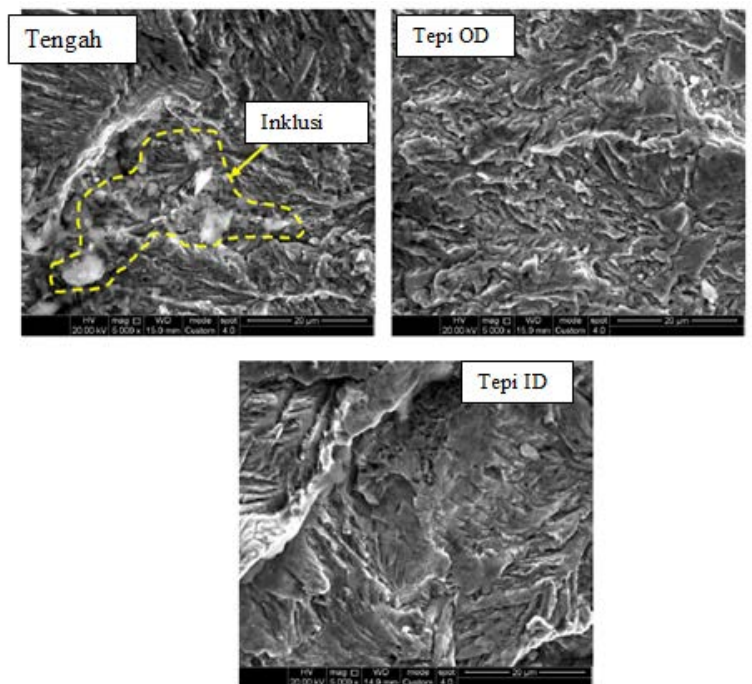

Gambar 4.12 Retak permukaan pada sampel A. Beberapa inklusi teramati
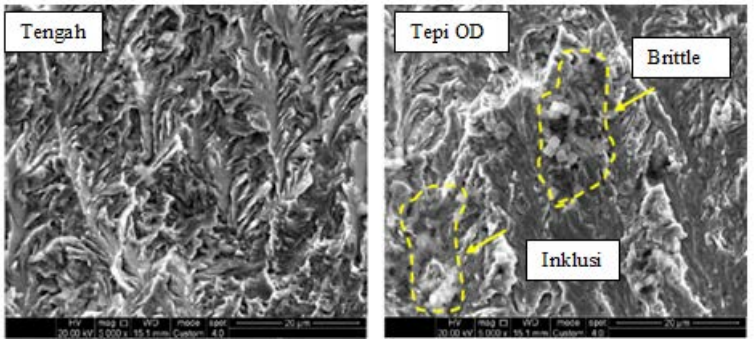

Gambar 4.13 retak permukaan pada sampel B.

Beberapa menunjukan ciri-ciri inklusi dan getas

\subsection{Analisa Mikro dengan EDS}

Analisa mikro dari kandungan kimia dan ciri-ciri lain yang ditemukan pada retak permukaan dianalisa menggunakan energy dispersive $X$-ray spectrometry (EDS) dengan hasil seperti yang ditunjukan pada Gambar 4.14.

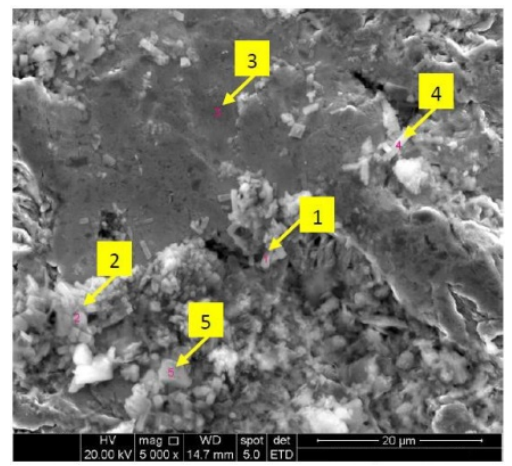

Gambar 4.14 Daerah pengambilan EDS pada cacat permukaan

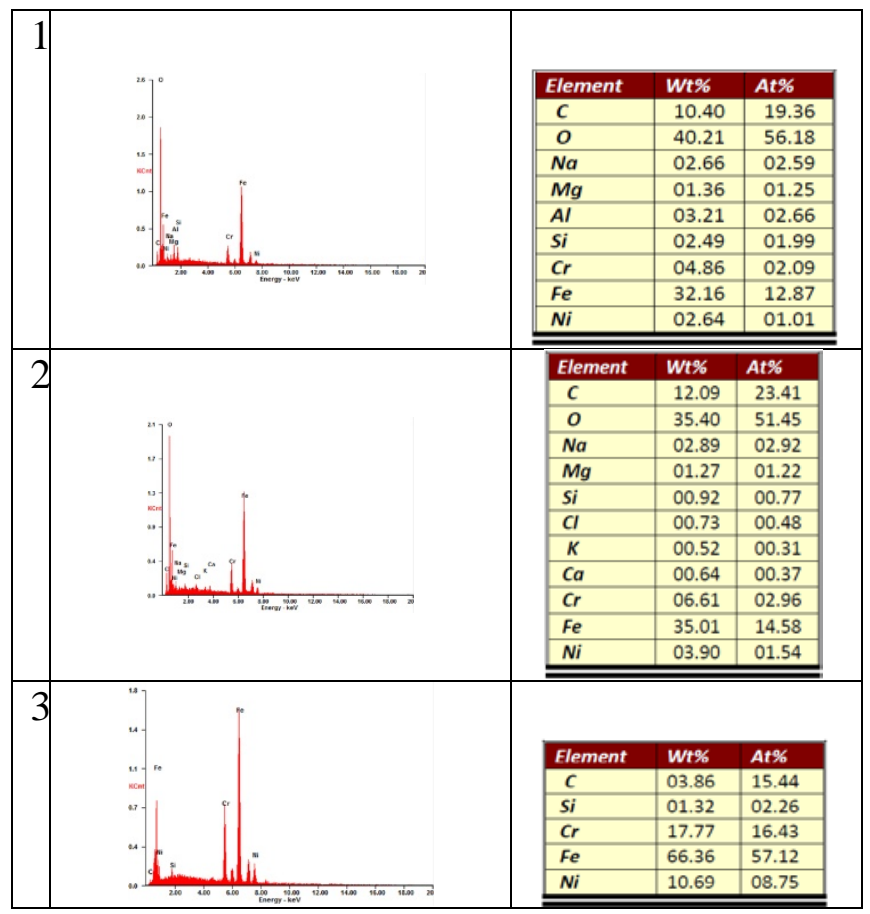




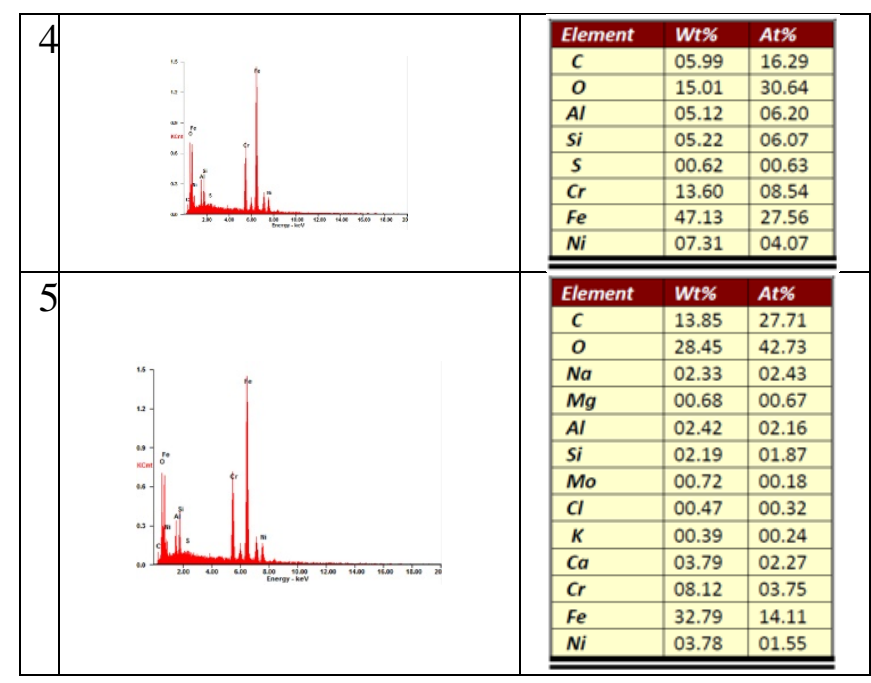

Klorida ditemukan sangat sedikit pada sampel nomor 2 dan nomor 5. Sulfur terlihat tetapi dengan jumlah yang sangat sedikit pada sampel nomor 4.

Analisa EDS juga dilakukan pada partikel getas yang terdapat pada logam lasan. Hasilnya dapat dilihat pada gambar 4.15.
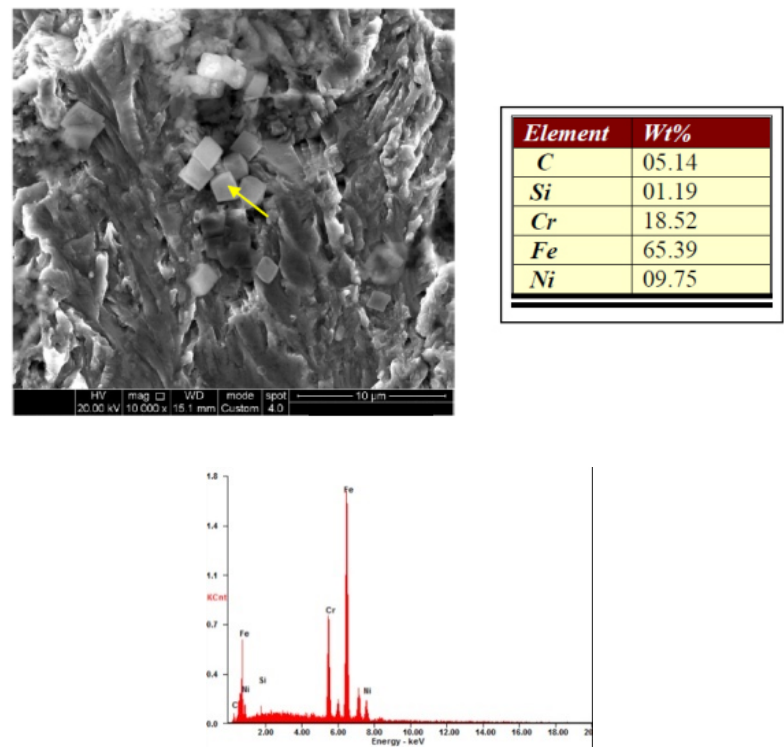

Gambar 4.15 Analisa EDS pada partikel yang di curigai

Dari hasil analisa dari EDS ditemukan bahwa partikel berasal dari bentukan logam paduan $\mathrm{Fe}-\mathrm{Cr}\left(\mathrm{Fe}_{\mathrm{x}} \mathrm{Cr}_{\mathrm{y}}\right)$.

\section{Pembahasan \\ Hot Cracking}

Berdasarkan Suutala diagram dapat dilihat kemungkinan adanya hot crack pada pengelasan baja tahan karat. $\mathrm{Cr}_{\text {eq }}$ dan $\mathrm{Ni}_{\text {eq, }}$, jumlah presentase Sulfur ditambah presentase Fosfor dapat dihitung dan besarnya dapat ditentukan pada diagram.

Hasil pengujian kimia spectography didapat kandungan unsur-unsur seperti yang ditunjukan pada
Tabel 4.5 .

Tabel 4.5 Komposisi kimia logam sambungan las yang mengalami cacat retak

\begin{tabular}{|l|c|c|c|c|c|c|c|c|}
\hline Unsur & $\mathrm{C}$ & $\mathrm{M}$ & $\mathrm{S}$ & $\mathrm{C}$ & $\mathrm{N}$ & $\mathrm{P}$ & $\mathrm{S}$ & $\mathrm{T}$ \\
\hline $\begin{array}{l}\text { Logam } \\
\text { lasan }\end{array}$ & 0,08 & 1,82 & 0,68 & 18,2 & 10,5 & 0,019 & 0,036 & 0,11 \\
\hline
\end{tabular}

Perhitungan $\mathrm{Cr}_{\mathrm{eq}}$ dan $\mathrm{Ni}_{\mathrm{eq}}$ untuk dipergunakan pada Suutala diagram adalah sebagai berikut:

$$
\begin{aligned}
& \text { Creq }=\mathbf{C r}+\mathbf{1} .37 \mathbf{M o}+\mathbf{1 . 5} \mathbf{S i}+\mathbf{2} \mathbf{~ N b}+\mathbf{3} \mathbf{~ T i} \\
&=18.2+1.5(0.68)+3(0.11) \\
&=19.55 \\
& \text { Nieq }=\mathbf{N i}+\mathbf{0 . 3 1} \mathbf{M n}+\mathbf{2 2} \mathbf{C}+\mathbf{1 4 . 2} \mathbf{~ N}+\mathbf{C u} \\
&=10.5+0.31(1.82)+22(0.08) \\
&=12.8242 \\
& \mathbf{C r}_{\mathbf{e q}} / \mathbf{N i}_{\mathbf{e q}} \quad=\mathbf{1 . 5 2} \\
&(\mathbf{P}+\mathbf{S}) \mathbf{\%} \quad=\mathbf{0 . 0 1 9}+\mathbf{0 . 0 3 6}=\mathbf{0 . 0 5 5}
\end{aligned}
$$

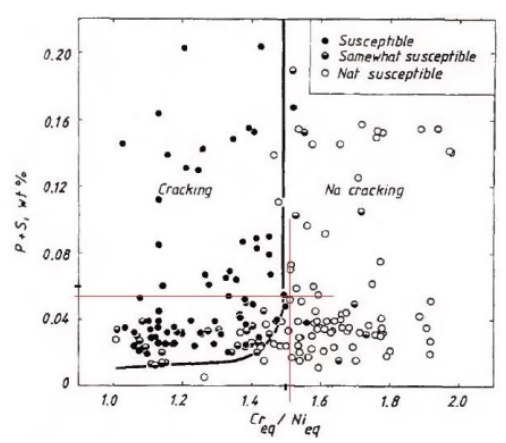

Gambar 4.16 Diagram Suutala untuk solidification cracking

Plot dari hasil perhitungan dari komposisi kimia ke diagram Suutala menunjukan posisi titik perpotongan berada sedikit di sebelah kanan kurva batas cracking dan no cracking.

Berdasarkan sifat-sifat dari karakteristik hot cracking :

1. Cracking muncul selama atau secepatnya pada saat pengelasan

2. Interdendritic atau intergranular cracking

3. Kandungan berlebihan dari Sulfur, Fosfor, atau Timbal dalam base metal.

Berdasarkan komposisi kimia, kandungan sulfur pada logam lasan sedikit melebihi kandungan yang harusnya ada pada ER 347, hal ini bisa saja menjadi faktor yang mendukung adanya hot cracking. Akan tetapi, beberapa hal tidak cocok dengan sifat-sifat hot cracking sebagai berikut:

1. Crack dimulai dari root. Bentuk khas dari hot cracking seharusnya berbentuk crater crack atau centerline crack.

2. Penyebaran crack dalam mode transgranular. Biasanya penyebaran crack pada hot cracking dalam mode intergranular.

3. Diagram Suutala menunjukan tidak adanya hot cracking. 


\section{Cold Cracking}

Berdasarkan hasil pengamatan struktur makro, crack dimulai dengan arah tegak lurus terhadaap permukaan base metal dan bergerak parallel terhadap axis las. Ketidaksempurnaan pada root (root underfill) pada daerah retakan cenderung mendapatkan konsentrasi stress, dan perbedaan ketebalan pada leher flange dengan pipa akan mengakibatkan pendinginan yang cepat dan thermal stress.

Ada daerah yang underfilled pada root, dengan bentuk seperti takik tajam pada crack tip, Hasil SEM pada retakan adalah retak transgranular. Crack mungkin tidak terdeteksi pada saat fabrikasi karena delayed cracking, memberikanharapan retakan disebabkan oleh cold cracking. Argumentasi yang mendukung adanya cacat retak disebabkan oleh cold cracking:

1. Penyebaran crack dalam modus transgranular

2. Lokasi crack dimulai dari root, yang merupakan hal umum pada cold cracking

3. Konsentrasi stress pada root (disebabkan takik tajam dan juga ditunjukan adanya indikasi distorsi) yang merupakan potensi pemicu cold crack

Akan tetapi, baja tahan karat austenitic mempunyai larutan hidrogen yang lebih rendah dari pada material feritik yang menyebabkan terhambatnya kemungkinan adanya hydrogen embrittlement. Selain itu berdasarkan struktur mikro material tidak ditemukan adanya struktur martensit yang rentan terhadap cold cracking.

Cold cracking biasanya timbul setelah 48 jam atau lebih setelah pengelasan, tetapi tidak ada dokumentasi dilakukannya radiography $100 \%$ atau tidak.

\section{Stress Corrosion Cracking}

Baja tahan karat tipe 321 merupakan jenis yang distabilkan dengan titanium untuk meningkatkan ketahanan terhadap korosi interganular, tetapi baja tahan karat jenis ini sangat sensitif terhadap larutan klorida $(\mathrm{Cl})$ atau dalam asam sulfur, bahkan dalam konsentrasi yang sedikit. Stress untuk jenis ini bisa saja terjadi dari dampak faktor operasi. Akan tetapi, hasil dari EDS menunjukan kontaminan klorida yang ada sangat sedikit untuk membuat SCC sebagai penyebab adanya kegagalan.

\section{Sigma Phase Embrittlement}

Perhitungan Modified Schaeffler-De Long

Rincian perhitungan Modified Schaeffler-De Long adalah sebagai berikut:

Tabel 4.6 Komposisi kimia logam sambungan las yang mengalami cacat retak

\begin{tabular}{|l|l|l|l|l|l|l|l|l|}
\hline Unsur & $\mathrm{C}$ & $\mathrm{M}$ & $\mathrm{S}$ & $\mathrm{C}$ & $\mathrm{N}$ & $\mathrm{P}$ & $\mathrm{S}$ & $\mathrm{T}$ \\
\hline $\begin{array}{l}\text { Logam } \\
\text { lasan }\end{array}$ & 0,08 & 1,82 & 0,68 & 18,2 & 10,5 & 0,019 & 0,036 & 0,11 \\
\hline
\end{tabular}

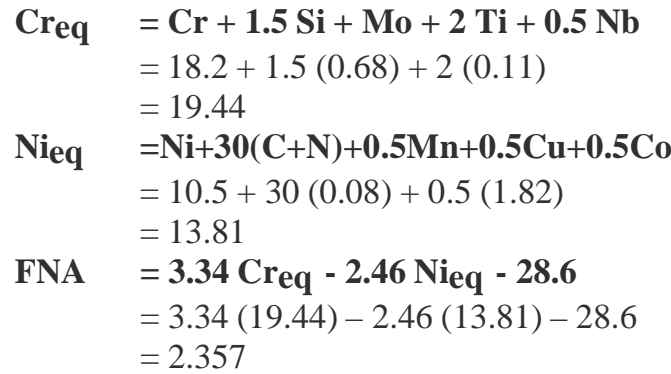

Menggunakan perhitungan diagram modified Schaeffler-De Long, ferrite number adalah 2.357. sementara pada hasil image analyzer ferrite number dapat diinterpolasi dan didapat sekitar 11.75. Hal ini karena transformasi dari ferrit ke fase sigma tidak secara volumetrik setara karena fase sigma memiliki konsentrasi $\mathrm{Cr}$ lebih tinggi dari ferit. Hasil EDS pada Gambar 4.14. menunjukan adanya fase sigma dengan kandungan krom dan besi yang tinggi.

Konsentrasi stress umumnya ditemukan setelah proses pengelasan. Hal ini dikarenakan performa dari pengelasan itu sendiri, dimungkinkan untuk juru las menggunakan arus tinggi dari yang dibutuhkan pada prosedur pengelasan, sehingga menghasilkan masukan panas yang tinggi. Tindakan ini dapat menyebabkan ekspansi dan menghasilkan stress yang berhubungan dengan itu.

Sifat dasar dari pengelasan pada material tipis memiliki kecenderungan pendinginan yang cepat. Pendinginan yang terlalu cepat dapat mengakibatkan berkurangnya keuletan dari material. Berkurangnya keuletan dapat dilihat dari hasil EDS yang menunjukan adanya pola retak rapuh (brittle fracture). Beberapa area di daerah fusi dan HAZ juga menunjukan adanya angka kekerasan material yang lebih tinggi dari base metal.

\section{KESIMPULAN}

Berdasarkan dari hasil dan pembahasan, maka dapat diambil beberapa kesimpulan, yaitu:

1. Bahan pipa dan flange sesuai dengan grade 321 dari stainless steel austenitic berdasarkan komposisi kimia dan kekerasan. Logam las seharusnya ER 347 dengan beberapa elemen (silicon, kromium dan sulfur) sedikit diluar parameter.

2. Hasil pengamatan Microphotografi dan microfotografi memperlihatkan adanya cacat lasan underfill pada root lasan dan distorsi las.

3. Pengamatan metalografi menunjukan menunjukkan kandungan ferrit 10, 5\% (11, 75 FN) yang memiliki kecenderungan kegetasan tinggi, yang memicu timbulnya phase sigma. Fase sigma menurunkan 
ketangguhan logam dan diduga terjadi pada saat pengelasan.

4. Pengujian mikrohardness menunjukan daerah dekat HAZ memiliki angka kekerasan Vickers (461 HVN dan 361 HVN) yang jauh lebih besar dibangingkan daerah lainnya

5. Berdasarkan hasil pengamatan fraktografi, mengungkapkan penyebab kerusakan adalah celah-celah inisiasi yang diduga dari root lasan dan merambat ke permukaan las luar. Bentuk retakan merupakan retak transgranular dan memiliki pola getas. Retakan pada root juga lebih lama dari pada permukaan luar. Konsentrasi tegangan pada root (timbul akibat ketidaksempurnaan pada bentuk root) dapat memicu retak. Retak kemudian merambat dari waktu ke waktu bersamaan tingkat stres.

6. Analisa mikro dengan EDS menemukan adanya kandungan kromium yang tinggi (18,52 \%Wt), partikel berasal dari bentukan logam paduan $\mathrm{Fe}-\mathrm{Cr}\left(\mathrm{Fe}_{\mathrm{x}} \mathrm{Cr}_{\mathrm{y}}\right)$.

7. Kerusakan disebabkan oleh performa pengelasan, dimungkinkan pengelasan menggunakan arus tinggi dari yang dibutuhkan pada prosedur pengelasan, sehingga menghasilkan masukan panas yang tinggi. Sifat dasar dari pengelasan pada material tipis memiliki kecenderungan pendinginan yang cepat yang mengakibatkan berkurangnya keuletan dari material.

\section{DAFTAR PUSTAKA}

API RP 571 - Damage Mechanisms Affecting Fixed Equipment in Refining Industry (2 ed.). (2011). Washington, USA: API Publishing Services.

Brooks, J. A. (1993). ASM Handbook Volume 6 - Welding Brazing and Soldering. ASM International.

Callister, W. D. (2009). Fundamentals of Materials Science and Engineering (8 ed.). (W. Anderson, Penyunt.) John Wiley \& Sons, Inc.

Corrosion of Stainless Steel Weldments. (2003).

Dalam S. D. Cramer, \& S. Bond (Penyunt.), ASM Handbook, Volume 13A Corrosion: Fundamental, Testing and Protection (hal. 301-316). Material Park, Ohio, USA: ASM International.
Davis, J. (Penyunt.). (1994). ASM Speciality Handbook Stainless Steel. Material Park, Ohio, USA: ASM International.

Davis, J. R. (Penyunt.). (2006). Corrosion of Weldment. Materials Park, Ohio, USA: ASM International.

Devold, H. (t.thn.). Oil and gas production handbook - An introduction to oil and gas production, transport refining and petrochemical industry (3 ed.). Oslo: ABB Oil and Gas.

Grub, J. F. (2005). Corrosion of Wrought Stainless Steels. Dalam S. C. Cramer (Penyunt.), ASM Handbook, Volume 13 B Corrosion: Materials (hal. 58). Materials Park, Ohio, USA: ASM International.

Handbook of Mechanical Alloy Design. (2004). Dalam G. E. Totten, L. Xie, \& K. Funatani (Penyunt.). New York, USA: Marcell Dekker, Inc.

Home: Hudson Products Corporation. (2009). Dipetik August 1, 2015, dari Hudson Products Corportation Web Site: http://www.hudsonproducts.com/products/ finfan/tech.html

(2000). ISO 8249:2000 Welding Determination of Ferrite Number (FN) in austenitic and duplex ferritic-austenitic Cr-Ni stainless steel weld metals. ISO.

Kidnay, A. J., \& Parish, W. R. (2006). Fundamentals of Natural Gas Processing. Boca Raton, Florida, USA: CRC Press.

Lippold, J. C., \& Kotecki, D. J. (2005). Welding Metallurgy and Weldability of Stainless Steel (1 ed.). Hoboken, New Jersey, USA: John Willey \& Sons.

Long, C. J., \& DeLong, W. T. (1973, July). The Ferrite Content of Austenitic Stainless Steel Weld Metal. Welding Research Supplement to The Welding Journal.

Mathers, G. (t.thn.). Welding of austenitic stainless steel. Part 2. Dipetik Agustus 1, 2015, dari TWI: http://www.twiglobal.com/technical-knowledge/jobknowledge/welding-of-austeniticstainless-steel-part-2-104/

P. Reed, R. ,. (1989, March). Nitrogen in austenitic stainless steel. The Journal of The Minerals, Metals \& Materials Society (TMS), 41(3), 16-21.

Singh, R. (Penyunt.). (2009). Weld Cracking in 
Ferrous Alloys. New Delhi, India: Woodhead Publishing India Pvt Ltd.

Speight, J. G. (2007). Natural Gas: A Basic Handbook. Houston, Texas, USA: Gulf Publishing Company. 